\title{
Полинг пленок хромофор-полимер в поле коронного разряда при изменении температуры для создания наведенной оптической нелинейности хромофора
}

\author{
$\underline{\text { В.В. Шелковников }}^{1,2, *}$, Е.В. Васильев ${ }^{1}$, Н.В. Васильева ${ }^{1}$, \\ С.В. Коротаев ${ }^{1}$ И.Ю. Каргаполова ${ }^{1}$, Н.А. Орлова ${ }^{1}$ \\ ${ }^{1}$ Новосибирский институт органической химии СО РАН \\ ${ }^{2}$ Новосибирский государственный технический университет \\ *E-mail: vice@nioch.nsc.ru
}

DOI: 10.31868/RFL2020.36

В настоящее время тонкопленочные органические нелинейно-оптические (НЛО) материалы хромофор-полимер, подходящие для изготовления высокоскоростных интегрированных электрооптических модуляторов, являются актуальным направлением исследований в области нелинейной оптики. Типичные исследования НЛО материалов хромофор-полимер проводятся при раздельном полинговании образца и измерении величины отклика генерации второй гармоники (ГВГ). В данной работе представлен метод, позволяющий проводить полинг одновременно с измерением сигнала ГВГ образца.

Создана установка полинга с возможностью мониторинга сигнала ГВГ материалов хромофор-полимер в реальном времени при одновременном нагревании образца и полинге в поле коронного разряда триодной системы полинга.. На экспериментальной установке полинга были определены условия эффективной ориентации молекул хромофора на основе полифтортриарилпиразолина и дицианозамещенного изофорона в микронных плёнках поликарбоната. Наведение сигнала ГВГ проводилось первой гармоникой импульсного Nd:YAG лазера 1064 нм. Измерены зависимости уровня сигнала ГВГ от потенциала на выравнивающей сетке и от потенциала на игольчатом электроде. Найдено оптимальное соотношение потенциала на игольчатом электроде к потенциалу на выравнивающей сетке: $\mathrm{U}_{\mathrm{n}} / \mathrm{U}_{\mathrm{g}}=2.6$, при котором происходит наиболее эффективный процесс полинга. По зависимостям роста сигнала ГВГ от напряжения на игле для разных температур полинга показано, что вблизи температуры стеклования полимерной плёнки хромофор-полимер существует оптимальная температура полинга $135^{\circ} \mathrm{C}$.

Получены временные зависимости термической релаксации ориентированных дипольных молекул хромофора в полимерной матрице при температуре стеклования полимера и при температурах, соответствующих растормаживанию $\beta$-релаксационной подвижности полимерных цепочек. Обнаружено, что процессы $\alpha$-релаксации при температуре стеклования полимера описываются моноэкспонентной зависимостью $\tau_{1}=3.5 \mathrm{c}$, в то время как релаксация при температурах, соответствующих растормаживанию $\beta$ релаксационной подвижности полимерных цепочек, описывается двухэкспонентной зависимостью $\tau_{1}=4 \mathrm{c}, \tau_{2}=25 \mathrm{c}$.

Работа была финансово поддержана грантом РНФ o. 16-13-10156 